\title{
TRINITAS DAN SIFAT TUHAN: Studi Analisis Perbandingan Antara Teologi Kristen dan Teologi Islam
}

\author{
Sri Dahlia \\ STAI PATI, Jawa Tengah, Indonesia \\ sri_dablia@gmail.com
}

\begin{abstract}
This paper emphasizes discussion on two traditions of Abrahamic religion, Islam and Christian who have more or less the same doctrine. Among these doctrinal similarities are the attributes of God. Various schools in Islamic theology differ on the existence of such attributes. Some say qadim and some say hadithas well as in the Christian tradition. In addition, this paper also elaborates the Mu'tazilite opinion that believes that the atributes of God as hadith contrasts with the opinion of Ash'ariyah. While in the Christian tradition that has a doctrine similar to the Mu'tazila is the understanding of the humanity of Jesus.
\end{abstract}

Keyword: Trinitas, Characteristic, God 


\section{Abstrak}

Tulisan ini menitikberatkan pembahasan pada dua tradisi Abrahamic religion, Islam dan Kristen yang memiliki ajaran dan doktrin yang kurang lebih sama. Di antara kesamaan ajaran dan doktrin tersebut adalah sifat-sifat Tuban. Berbagai aliran dalam teologi Islam berbeda pendapat mengenai eksistensi sifat-sifat tersebut. Ada yang mengatakan qadim dan ada yang mengatakan hadits demikian halnya pada tradisi Kristen. Di samping itu tulisan ini juga mengelaborasi pendapat Mu'tazilah yang meyakini bahwa sifat Tuban sebagai hadits yang kontras dengan pendapat Asy'ariyah. Sementara dalam tradisi Kristen yang memiliki ajaran yang senada dengan Mu'tazilab adalab paham mengenai kemanusiaan Yesus.

Kata Kunci: Trinitas, Sifat, Tuban.

\section{A. Pendahuluan}

Agama Kristen merupakan agama wahyu yang memiliki kepercayaan monoteistik yang diwarisi oleh Ibrahim, sebagaimana Yahudi dan Islam. Bahkan agama yang dibawa oleh Yesus Kristus atau yang dalam Islam dikenal dengan Isa al-Masih ini merupakan penerus dari agama Yahudi sebelumnya. Adalah niscaya jika Kristen mengajarkan bahwa segala hukum Taurat dan kitab-kitab perjanjian lama serta tradisi-tradisi lama yang hidup pada masa sebelumnya wajib ditaati oleh pemeluknya. ${ }^{1}$ Yang membedakan agama Kristen dengan kedua agama lainnya adalah adanya unsur keselamatan yang dilakukan Yesus Kristus untuk umatnya. Unsur inilah yang kemudian melahirkan doktrin trinitas.

Sebagai pewaris dari agama Ibrahim (Abrahamic Religion), Kristen pada awalnya memiliki konsepsi monoteisme yang sama dengan Islam, namun sepeninggal Yesus pembawa agama ini dan masuknya budaya luar serta faktor politik dari penguasa saat itu, konsepsi monoteisme dalam agama semitis ini menjadi kabur dengan munculnya doktrin trinitas, yakni doktrin kepercayaan

${ }^{1}$ Lihat Matius: 17-19 
terhadap tiga oknum ketuhanan: oknum Bapak, Putra dan Roh Kudus atau tiga sifat ketuhanan, ${ }^{2}$ dan ketiga oknum ini bersifat kekal atau qadim. ${ }^{3}$

Dalam sejarah, konsepsi trinitas yang difahami oleh umat Kristen tersebut menimbulkan reaksi keras baik dari kalangan Kristen sendiri seperti Arianisme serta beberapa sekte dari kalangan Islam seperti Asy`ariah, Salafiyah maupun Mu`tazilah. Dan Mu tazilah memiliki karakteristik tersendiri dalam merespon trinitas. Mereka mengkritik dan menolaknya dengan konsep ta til yaitu penolakan terhadap sifat-sifat Tuhan.

Sebenarnya mereka tidak mengingkari keberadaan sifatsifat Allah tetapi mereka menolak adanya sifat-sifat yang qadim dan difahami sebagai tambahan atas zatNya. Konsepsi penolakan terhadap sifat-sifat Tuhan yang qadim yang terpisah dari zatNya ini merupakan antithesis dan counter terhadap trinitas Kristen yang oknum-oknumnya difahami sebagai yang qadim, bahkan terhadap golongan-golongan Islam sendiri yang meyakini sifat-sifat Tuhan sebagai yang qadim.

Penolakan Mu`tazilah tersebut tidak berlebihan ketika kita menengok sejarah gereja Kristen. Trinitas bukanlah risalah yang dibawa oleh Yesus Kristus tetapi merupakan produk pemikiran para tokoh gereja klasik yang dilembagakan sebagai doktrin gereja Ortodoks pada abad ke-4 Masehi. Dan doktrin tersebut tidak lepas dari pengaruh Helenisme yang saat itu menjadi wacana global.

Pada abad kedua dan ketiga masehi, kepercayaan Kristen sudah terpengaruh dengan kebudayaan Yunani dan mulai bergumul dengan gnosis. Apalagi perkembangan Kristologi pada abad pertama yang menggeser posisi Yesus, yang melalui kebangkitannya dinyatakan sebagai anak Allah. Pada diri

${ }^{2}$ Abu Al-Fatih Muhammad Abu al-Karim Ibn Abu Bakar al-Syahrastani, Al-Milal wa an-Nihal, (Bairut: Dar al-Fikr, tt), hlm. 222

${ }^{3}$ Henry C. Theissen \&Vernon D.Doerksen, Teologi Sistematika (Malang: Yayasan Penerbit Gandum Emas, 1997), hlm.138 


\section{Sri Dahlia}

Anak Allah ini firmanNya sudah ada sebelum tampil di bumi. Pendekatan ini mudah diterima oleh penganut gnosis Yunani. Dan sebaliknya, pandangan gnosis tidak menerima jika Yesus juru selamat adalah seorang manusia.

Benih trinitas tersebut tumbuh dan dipupuk dalam perguruan Aleksandria, yaitu perguruan tinggi pertama dan terpenting didirikan di kota Aleksandria Mesir. Mazhab Aleksandria bergerak dalam alam pemikiran filsafat yang berpangkal pada Plato dan terpengaruh oleh gnosis Yunani. Sedangkan yang menentang keazalian oknum-oknum adalah (ketuhanan Yesus) adalah perguruan tinggi Teologi Antiokhia di Syria. Mazhab Antiokhia juga bergerak dalam pemikiran filsafat Yunani tetapi lebih terpengaruh oleh filsafat Aristoteles yang bersifat positivistik, kurang mistik dan bersifat lebih rasional daripada mazhab Aleksandria. Dalam eksegese (hermeneutik), mazhab Antiokhia menegaskan segi historisitas harfiah kitab suci serta kurang gemar akan alegorese. ${ }^{4} \mathrm{Namun}$ kecenderungan monotheistik mazhab ini kemudian dianggap bid`ah dan menyimpang dengan diresmikannya doktrin trinitas oleh Konstantin penguasa Romawi saat itu dalam Konsili Nicea tahun 325 Masehi.

Melalui penelitian ini, disamping dalam rangka mengetahui doktrin trinitas dalam tradisi Kristen Klasik, penulis ingin mengkaji lebih dalam doktrin sifat-sifat Tuhan dalam tradisi teologi Islam kususnya Mu'tazilah dan membandingkannya dengan doktin trinitas dalam teologi Kristen. Karena sekte ini dianggap paling konsisten dalam mempertahankan ajaran monotheisme dibandingkan sekte-sekte Islam lainnya. Kritik dan penolakan mereka terhadap sifat Tuhan yang qadim berimbas pada kritik mereka terhadap doktrin trinitas dalam teologi Kristen.

Berbeda dengan kajian Kristologi sebelumnya yang cenderung bias dan terkesan mendiskriditkan agama lain, sehingga

${ }^{4}$ C. Groenen, Sejarah Dogma Kristologi: Perkembangan Pemikiran Yesus Kristus pada umat Kristen (Yogyakarta: Kanisius, 1987), hlm.115 
tidak dapat menimbulkan dialog yang sehat dengan sesamanya yang beragama lain. Terlepas dari kekeliruan yang dialamatkan pada keyakinan Kristen tersebut, penulis tidak akan menyoroti kekeliruan tersebut tetapi lebih memfokuskan pada hubungan erat antara doktrin trinitas dengan sifat Tuhan dalam dua tradisi Kristen dan Islam. Kesepahaman dan ketidaksepahaman antara dua tradisi tersebut.

Penulis merasa tergugah untuk meneliti kajian ini mengingat stereotip-stereotip yang muncul karena ketidaktahuandan sikap penuh dengan prasangka negatif baik tentang Islam maupun tentang Kristen sendiri yang berlangsung selama ratusan tahun. Sedangkan perhatian sarjana-sarjana muslim terhadap Barat (tradisi Kristiani) selama ini tidak sebanding apabila dibandingkan perhatian intelektual Barat terhadap Timur (tradisi Islam). Maka adalah niscaya ketika ada kesalahpahaman-kesalahpahaman atau klaim-klaim yang muncul di kalangan umat Islam mengenai keyakinan agama Kristen. Fenomena ini sangat merugikan umat Islam sendiri. Maka perlu diadakan kajian teologis terhadap keyakinan agama Kristen dengan melihat persamaannya dan perbedaannya dalam konsepsi teologi Islam, yakni persamaan oknum-oknum trinitas dengan sifat-sifat Tuhan.

Pengidentikan oknum-oknum dengan sifat-sifat ini sebenarnya sudah tidak asing lagi dalam teologi Kristen dan Islam abad pertengahan. Saat kedua teolog dari kedua agama tersebut hidup berdampingan di bawah kekuasaan Islam. Namun setelah abad pertengahan berlalu, pengidentikan dua term dari dua tradisi agama yang berbeda ini mulai terkubur dan dilupakan oleh para teolognya baik dalam Islam maupun dalam Kristen sendiri, apalagi dalam konteks keindonesiaan. Dengan demikian, di sinilah letak urgensi dari penelitian ini.Kajian ini difokuskan pada doktrin trinitas dan sifat Tuhan dalam teologi Kristen dan Islam. Secara teologis dalam kedua agama ini memiliki persamaan dan perbedaan konsep mengenai kedua ajaran tersebut. 
Dalam teologi Kristen Allah telah menyatakan dan memperkenalkan dirinya sebagai yang Esa. Di dalam ajaran Kristen, Allah yang dengan firman dan karyaNya menyatakan atau memperkenalkan diri sebagai Bapa, Putra dan Roh Kudus. Keyakinan ini disebut trinitas atau tritunggal. Ajaran trinitas, Allah bukanlah suatu kebenaran yang diperoleh melalui akal budi atau yang dikenal dengan istilah teologi natural, tetapi suatu kebenaran yang dapat diketahui melalui penyataan atau wahyu. Bentuk Yunani dari trinitas adalah trias. Dan istilah ini pertama kali digunakan oleh Tertulianus (w. 220M).

Dalam teologi Kristen, istilah trinitas berarti ada tiga oknum yang kekal dalam hakikat Allah yang Esa. Masing-masing dikenal sebagai Allah Bapa, Putra dan Roh Kudus. Tiga oknum ini dikenal sebagai tiga kepribadian Allah. Ketiganya adalah kesatuan yang merupakan satu kebenaran yang Esa. Menurut rumusan gereja Kristen, keyakinan yang demikian tidak boleh disebut sebagai politeisme tetapi harus dikatakan sebagai suatu model dari monoteisme, sebab oknum kedua dan ketiga merupakan bagian dari Allah sang Bapa. Dengan istilah lain bahwa ketiganya adalah dalam keesaan atau keesaan dalam ketigaan. ${ }^{5}$ Dua pengertian ini secara umum dapat memberikan penekanan yang berbeda terhadap doktrin trinitas dalam sejarah perkembangannya. Maka terdapat dua tipologi kecenderungan terhadap trinitas, yaitu kecenderungan teologi Yunani dan Latin. Kecenderungan pertama lebih menekankan pada substansi oknum-oknumnya, sedangkan yang kedua lebih menekankan pada keesaan ketiga oknum-oknum tersebut. maksudnya adalah kesempurnaan ketuhanan terletak pada kesatuan oknum-oknumnya. Pendekatan ini desebut modalisme, yakni oknum tersebut hanya modus dari keesaan Tuhan, ${ }^{6}$ atribut atau dalam Islam disebut dengan sifat Tuhan.

${ }^{5}$ HM. Arifin Mpd, Menguak Misteri Ajaran-Ajaran Agama Besar, (Jakarta: PT Golden Terayon Press, 1997), hlm. 143

${ }^{6}$ Eliade, Mircea, The Encyclopedia of Religion(New York: Simon and Schi - 
Dalam mengkaji sifat Tuhan, penulis lebih memfokuskan pada ajaran Mu`tazilah. Karena teologi ini sangat jelas dan tegas dalam menyuarakan konsep monoteismenya. Dengan rasionalismenya, Mu ‘tazilah memperjuangkan monoteisme atau tauhid murni melalui penolakannya terhadap sifat-sifat Tuhan yang dianggap qadim dan memiliki eksistensi sendiri di luar dzatNya.

Sebenarnya Mu`tazilah tidak mengingkari keberadaan sifat-sifat Allah tetapi mereka menolak adanya sifat-sifat yang qadim dan difahami sebagai tambahan atas zatNya. Dengan berpegang pada pemahaman mengenai keesaan Tuhan, mereka mengakui adanya penyatuan antara zat dan sifat.

Penolakan Mu`tazilah terhadap sifat Tuhan yang qadim ini merupakan landasan teori mereka dalam mengkritik doktrin trinitas dalam teologi Kristen. Karena oknum-oknum atau dalam teologi Islam lebih dikenal dengan sifat, oleh teologi Kristen difahami sebagai yang qadim atau kekal. Pemahaman ini berimplikasi pada naiknya posisi yesus sebagai firman kepada derajat ketuhanan.

Dalam memurnikan monoteisme ini, Mu`tazilah tidak hanya mendapatkan perlawanan dari teolog Kristen, tetapi mendapatkan perlawanan juga dari sesama teolog muslim terutama dari teolog Asy`ariah yang meyakini sifat sebagai yang qadim. Dan para teolog Mu`tazilah mengkhawatirkan para teolog Asy`ariah yang meyakini sifat sebagai yang qadim akan mengikuti jejak keyakinan trinitas Kristen.

Dalam penelitian ini, penulis menggunakan metode deskriptif dan komparatif analisis, yaitu dengan mengumpulkan data-data dari sumber-sumber yang ditentukan dengan menghubungkan satu sumber dengan sumber yang lain lalu kemudian menganalisisnya. Dengan demikian pengumpulan data dilakukan dengan cara survey buku (library research). Sedangkan

ter Mc. Milan, 1993), hlm.55 


\section{Sri Dahlia}

sumber penulisan, penulis berpedoman kepada buku-buku yang tercantum dalam daftar pustaka.

Penulis memahami sudah tentu kajian ini sangat diharapkan keautentikanya, yakni pembahasanya terhadap karyakarya para teolog Kristen maupun Islam. Dari teologi Kristen, penulis menggunakan buku-buku karangan para teolog Kristen dan Barat seperti C. Groenen, Karl Barth, Auster G Mc Graft. Dan dari teologi Islam, penulis mengambil sumber data dari karya-karya teolog Mutazilah klasik maupun modern dari Harun Nasution,Zuhdi Jarullah, Al-Khayyat, Qhadi Abd dan Jabbar. Sedangkan sumber data perbandingan antara Trinitas dan Sifat Tuhan penulis dapatkan dari para teolog dari kedua tradisi tersebut, Kristen dan Islam seperti Karen Amstrong, CJ. Bleeker, W.M. Watt,Anton Wessels,Harry A. Wolfson, Syalabi, Nasri Sihab, Muhammad Arkoun, dan Sayyed Husen Nasr.

Dalam penelitian ini, penulis memposisikan diri bukan sebagai pihak luar (out sider) sebagai pihak Mu`tazilah yang mengkritik doktrin Trinitas, tetapi sebagai orang dalam (insider) atau yang lebih tepat lagi melalui study from within yaitu sebagai pihak yang mencoba memahami trinitas dengan mempertimbangkan backrground tradisi Kristen dan kemudian dikomparasikan dengan pemikiran sifat Tuhan Mu`tazilah dalam tradisi Islam.

Penelitian ini memiliki tujuan teoritis dan praktis. Tujuan teoritisnya adalah pertama, dalam rangka memperkaya khazanah ilmu-ilmu pengetahuan dan keagamaan bagi akademisi dalam rangka memahami ajara-ajaran agama lain secara obyektif. Kedua, memfaktualkan ilmu-ilmu klasik yang berkaitan dengan perbandingan agama disaat bermunculanya kajian ilmuilmu modern dewasa ini. Sedangkan tujuan praktisnya adalah membiasakan para akademisi muslim untuk berfikir filosofis dalam menghadapi realitas yang ada. Karena dengan paradigma filsafat, umat Islam lebih rasional dalam menyikapi realitas yang ada dalam masyarakat. Tidak mudah emosi dan terpancing dengan pemahaman-pemahaman yang dangkal dalam wacana 
teologis khususnya. Sehingga diharapkan paradigma penelitian ini diharapkan dapat memberikan solusi konstruktif alternatif terhadap persoalan-persoalan konflik keagamaan yang sering terjadi di Indonesia maupun dunia lainya.

\section{B. Pembahasan}

\section{Sekte-Sekte Kristen klasik}

Agama Kristen yang ditemui nabi Muhammad dan kaum muslimin awal dapat dikatakan amat berbeda dengan agama Kristen yang kita kenal sekarang. Sekitar tahun 600an M ada sekelompok khusus umat Kristen yang melembagakan gereja besar yang belakangan terpisah dan kini terpecah menjadi gereja Katolik Roma, gereja ortodoks Timur dan gereja Protstan. Namun ada pula segolong umat Kristen yang telah keluar dari gereja besar tersebut seperti golongan heretik (bid `ah). Yang disebut terakhir ini sering disebut sebagai golongan Monofisit (golongan Yakobit dan Copt) dan golongan Nestorian. Keduanya dianut oleh sebagian besar umat Kristen Mesir, Palestina, Syiria dan Iraq (Watt: 1996,1) serta wilayah lainya yang diperintah kekhalifahan Islam. Namun bukan berarti penyimpangan mereka karena terpengaruh oleh pemikiran Islam, ${ }^{7}$ tetapi lebih terpengaruh oleh kecenderungan budaya masing-masing yang sangat berbeda dengan gereja bsar (orthodox state). Karena Islam datang kemudian dan bertemu dengan Kristen setelah agama ini melewati masa-masa kritisnya di abad 3,4 dan 5M dalam konsili-konsili yang menganggap keduanya sebagai heretik. Misalnya di wilayah Syam dan Mesir yang telah dikuasai Islam. Islam bertemu mereka dalam kondisi sudah mapan, karena sudah memeluknya sejak zaman jahiliayah melalui para rahib dan misionaris (Subhi: 1969,24). Dianggap heretik karena menentang dan menyimpang dari ajaran gereja besar. Adapun sekte-sekte Kristen klasik adalah:

${ }^{7}$ TJ. De Boer, The History of Philosophy on Islam, (New York: TP,TH), hlm.11 


\section{Sri Dahlia}

a. Mulkaniyah (orthodox State)

Istilah orthodox diambil dari bahasa Yunani ortodoxy yang mempunyai arti kepercayaan yang benar, yakni kepercayaan dan ajaran yang diakui oleh gereja sebagai yang berdasar pada pewahyuan dari Allah dalam Yesus Kristus. Ortodoksi masuk dalam perbendaharaan kata gerejani ketika terjadi perbedaan pendapat besar-besaran mengenai Kristologi dan tritunggal pada abad 3,4 dan 5M. Di Timur istilah ini digunakan untuk menyebut gereja-gereja yang bersatu dengan Konstantinopel dan Roma, dilawankan dengan Nestorian dan Monofisit . Atau gereja ortodoks ini disebut juga dengan gereja ortodoks Bizantium (Melkitis), Chalcedonis, Ortodoksi keras atau ortodoksi Yunani yang kini telah benar-benar menjadi gereja ortodoks. ${ }^{8}$ Dikatakan ortodoksi Yunani karena sekte atau ajaran ini berada di bawah payung kebudayaan Yunani yang sangat percaya kepada ortodoksi. Maka tak pelak lagi kalau kawasan timur gereja besar ini dikenal sebagai gereja ortodoksi, yang karenanya dapat dikatakan di sini bahwa persetujuan-persetujuan paripurna kepada kepercayaan tersebut diyakini menjadi landasan bagi persatuan umat Kristen. Visi ortodoks dari homogenitas komunitas pada iman dan persatuan dalam peribadatan adalah penting bagi gereja sebagai suatu keseluruhan, namun pada prakteknya visi ini dapat diselewengkan kepada alat mayoritas yang dominan untuk berbuat tirani kepada minoritas. Ortodoksi menjadi berarti pengakuan rumus-rumus kredal. Dan dari pengertian inilah subyek negosiasi antara berbagai macam golongan pada konsili-konsili ekumenikal terjadi. Dalam negosiasi ini golongan minoritas seperti masyarakat Kristen Mesir dan Syiria yang tidak mendapat tempat, lalu harus memilih antara meninggalkan sebagian kepercayaan mereka yang paling mendalam atau meninggalkan gereja besar. ${ }^{9}$

\section{$\operatorname{hlm} .7$}

${ }^{8}$ Anton Wesseles, Arab dan Kristen: Gereja-Gereja Kristen di Timur Tengah,

${ }^{9}$ (Jakarta: Gaya Media Pratama, 1996),hlm.4 
Aliran ortodoksi ini memiliki kekuasaan di Romawi yang mayoritas penduduknya menganut mazhab tersebut. Diantara tokohnya adalah Klement (w. 215) dari Aleksandria yang tentu saja mau meneruskan tradisi mewartakan seorang Yesus Kristus dari Yunani. Ia sangat menonjolkan sisi keilahian Yesus sedemikian rupa sehingga sisi kemanusiaanya yang secara formal dipertahankan nyatanya diserap oleh ciri ilahi. Misalnya ia bekata bahwa Yesus Kristus makan dan minum bukanlah karena membutuhkanya sebab daya penyangga Yesus adalah logos (firman) ilahi. Yesus makan dan minum supaya orang sekitarnya tidak mendapat kesan bahwa kejasmanianya hanya bayangan saja. ${ }^{10}$

Tokoh lain yang tergabung dalam aliran ini menurut Watt adalah Gregory dan Nyssa (w.359M). Mereka adalah salah seorang yang bertanggungjawab akan munculnya doktrin trinitas dalam konsili Konstantinopel tahun 381M. Dalam konsili ini dinyatakan bahwa Kristus adalah manusia seperti kita. Namun sebagai Bapa tidak sama seperti manusia biasa. Gregory menekankan bahwa pada diri Yesusterlihat watak oprasional yang identik dengan diri sang Bapa, yakni memberi kehidupan dan kesehatan yang membersihkan dosa dan memberikan petunjuk. ${ }^{11}$

Secara umum sekte ini meyakini bahwa kalimat bersatu dalam tubuh Yesus dan mengenakan tubuh kemanusiaanya. Penyatuan ini tidak sempurna. Bercampurnya kalimat dalam tubuh Yesus seperti bercampurnya air dengan susu. Sekte ini menegaskan bahwa substansi bukanlah oknum-oknum sebagaimana yang disifati (mausuf) bukanlah sifat itu sendiri. Dengan demikian mereka membedakan antara Bapa, Putra dan Roh Kudus dan menetapkan trinitas. Menurut mereka Yesus adalah qadim sejak azali. Maria telah melahirkan Tuhan yang azali,

\footnotetext{
${ }^{10}$ Groeneon, Sejarah Dogma, hlm. 116

${ }^{11}$ WM. Watt, Titik Temu, hlm.4
} 


\section{Sri Dahlia}

maka ia adalah ibu Tuhan. Pembunuhan dan penyaliban terjadi pada lahut dan nasut secara bersamaan. ${ }^{12}$

b. Ya kubiyah (monofisit church)

Istilah monofisit berasal dari bahasa Yunani yang berarti monos (satu) dan physys (kodrat) satu kodrat. Yaitu suatu gereja yang memiliki ajaran bahwa pada diri Yesus hanya ada satu kodrat. Akibat persatuan logos ilahi dengan kemanusiaan Yesus maka yang tinggal hanya satu kodrat, yakni kodrat ilahi. Sebab kemanusiaanya diresapkan ke dalam keilahian laksana setetes air madu jatuh ke dalam samudra. Sehingga rumusan konsili Ekumenis Efesus (431M) bahwa kodrat ilahi dan kodrat manusiawi Kristus tidak bercampur dan tidak terpisahkan, dan bahwa kodrat manusiawi dimiliki oleh pribadi ilahi disangkal oleh Eutikes sebagai tokoh utamanya. Ajaranya ini dianggap ekstrim dan dikutuk konsili ekumenis Chalcedon (451M). ${ }^{13}$ Tokoh gerejani lain yang berkecenderungan monofisit adalah Appolinaris yang sejak 361M menjadi uskup di Lordikea. Dan Athanasius (373M) juga termasuk ke dalam aliran ini.

Pendukung fanatik sekte ini sangat memusuhi para pengikut Nestorius, dan menyatakan satu tabiat serta meniadakan kemanusiaan Putra Tuhan yang menjelma dalam tubuh Yesus. Sehingga mereka dikatakan sebagai golongan Monofisit (satu tabiat). Kesatuan sempurna antara lahut dan nasut menjadi satu substansi. Yesus menurut mereka adalah Tuhan yang benar. Yakni dari substansi Bapaknya. Kemanusiaanya merupakan penampakan dari substansi ketuhanan, maka ia menjadi Tuhan. Manusia menjadi Tuhan seperti halnya bara yang menyala menjadi api. Dan pembunuhan terjadi pada tabiat yang satu, yaitu penyatuan antara lahut dan nasut. ${ }^{14}$

c. Nusturiyah (Nestorian Church)

${ }^{12}$ Ahmad Mahmud Subhi, Fi Ilmi al-Kalam,: Dirosah Falsafiyyah (DM: Dar al-Kutub al-Jamiyyah,1969) hlm. 43

${ }^{13}$ A. Heuken, Ensiklopedi Gereja, hlm. 187

${ }^{14}$ Subhi, Fi Ilmi al-Kalam, 44 
Nestorian merupakan nama gereja Timur kuno abad ke-5 yang pada abadke-19 ini berubah namanya menjadi Assyrian. ${ }^{15}$ Nestorian adalah aliran Kristen yang dipelopori oleh Nestorius dan dianggap sebagai ajaran heretik oleh gereja besar. Ajaran seorang rahib dari Antiokhia yang menjadi patrikh di Konstantinopel (428-431) ini dikutuk pada tahun 431 dalam konsili Efesus, karena mengajarkan dalam diri Yesus ada dua pribadi yang berbeda, manusiawi dan ilahi. ${ }^{16}$ Kemudian manusiawi Yesus menyatu dengan oknum kedua. Penyatuan yang dimaksud bukanlah dengan dengan pembauran sehingga menjadi satu, atau bukan penyatuan yang hakiki tetapi bermakna majazi. Dengan tegas Nestor menegaskan bahwa Yesus adalah manusia bukan Tuhan. Akibatnya ia dikeluarkan dari gereja, dipecat dan dinyatakan sebagai orang yang terlaknat.

Sekte ini meyakini bahwa kalimat menjelma dalam tubuh Yesus tidak melalui percampuran tetapi seperti halnya sinar matahari pada Kristal atau seperti munculnya cetakan cincin pada lilin. Ia adalah manusia yang lahir dari manusia. Akan tetapi berbeda dengan para rosul lainnya, anugrah ketuhanan diberikan kepadanya selamanya. Yaitu selama kalimat ketuhanan Nampak jelas dalam tabiat kemanusiaanya sebagaimana sinar matahari di atas Kristal. Kristal tidak menjadi matahari seperti halnya cetakan cincin di atas lilin,tidak membuat lilin ini menjadi cincin. Ia hanya gambar cincin, begitu juga dengan pertemuan ketuhanan. Setelah bertemu dengan kalimat, Yesus tidak menjadi Tuhan. Karena pertemuan itu tidak menggugurkan keazalian lahut dan kemakhlukan nasut. Sedangkan pembunuhan terjadi hanya pada nasut tidak pada lahut. Maria, ibu Yesus adalah manusia dan Yesus disebut Putra Allah karena pengangkatan atau anugrah bukan kelahiran atau penyatuan. Kecederungan semacam ini menyebabkan pengusiran Nestor. Akan tetapi peikiranya ini telah menyebar dalam masyarakat Syiria, dan merupakan

\footnotetext{
${ }^{15}$ Eliade, The Encyclopedi, hlm.369

${ }^{16}$ Gerald, Kamus Teologi, hlm.215
} 


\section{Sri Dahlia}

revolusi atas imperium Romawi dan sekte kerajaan (Mulkaniyah). Setelah dibantai oleh imperium Romawi, golongan ini menetap di wilayah Timur dan dilindungi oleh imperium Persia karena motif politis. ${ }^{17}$

Menurut golongan ini Tuhan itu kekal abadi dan tidak dapat dilampaui. Berdasarkan alasan tersebut maka golongan ini memberi obyek kepada Term Theodoks atau "Tuhan beranak" yang dikembalikan pada Maria. Karena Tuhan itu kekal abadi maka Tuhan tidak mungkin menjadi seorang bayi yang pernah dilahirkan manusia. Nestorius dan pengikutnya memberi penekanan pada hakikat kemanusiaan Yesus. Sebab pendapat kemanusiaan inilah yang membawa kemenangan atas setan. Karena sebagai manusia ia digoda, namun godaan-godaan yang diarahkan kepadanya selalu menemui kegagalan dengan adanya pribadi ilahi.

Bersatunya firman dengan Yesus bukan melalui perpaduan seperti yang diyakini oleh Mulkaniyah. Dan juga bukan merupakan penampakan diri sebagaimana yang difahami Ya kubiyah, akan tetapi bagaikan sinar matahari di dalam memancarkan sinarnya kepada benda yang dapat mengembalikan sinarnya kepada benda yang dapat mengembalikan sinarnya secara rata dan teratur. ${ }^{18}$ Karena dalam rangka penyatuanya dengan firman Tuhan atau Yesus pra eksisten atau Putra Tuhan sebenarnya, difahami sebagai pengangkatan bukan kelahiran sebagaimana diekspresikan oleh pelopornya yang lain Theodore Mopsuestia. ${ }^{1}$ Pemahaman terhadap pengangkatan Anak Yesus ini membedakan dengan pemahaman sekte Mulkaniyah dan Ya kubiyah yang menganggapnya sebagai anak kelahiran. Maka pantas sekte yang satu ini dianggap sebagai sekte yang memiliki pemahaman yang benar mengenai Yesus, paling tidak oleh Ibn Haith dan Hadatsi dari kalangan teolog muslim. Mereka

${ }^{17}$ Subhi, Fi Ilmi al-Kalam, hlm.43

${ }^{18}$ Al-Ghozali, Yesus Dalam Pandangan Al-Ghozali,penyaji Muhammad A dullah Assarqawi, Terj. Hasan Abrari (TK: Pustaka Dai, 1999), hlm.187

${ }^{19}$ Harry A.Wolfson, The Philosophy of Kalam(London: Harvard University Press, 1976),hlm.318 
menyebutkan bahwa kepercayaan yang benar mengenai Yesus bukan Mulkaniyah, bukan pula Ya kubiyah tetapi Nestorian.

Ketiga sekte Kristen ini sepakat bahwa Allah satu dari segi esensi dan tiga dari segi oknum. Oknum-oknum merupakan sifat-sifat wujud, ilmu dan hayat atau merupakan pribadi-pribadi: Bapak, Putra dan Roh Kudus. Oknum kedua yang merujuk pada ilmu menjelma dalam tubuh Yesus, maka bertemulah ketuhanan dan kemanusiaan. Bagaimana Maria yang hadits (makhluk) dapat melahirkan Tuhan sedangkan Tuhan adalah qadim. ${ }^{20}$

Pada umumnya orang Arab Kristen adalah pengikut gereja Timur (Nestorian), tetapi ada juga yang berada di bawah penganut Yakobit. Rahib Bahira yang diduga pernah bertemu dengan nabi Muhammad pada masa remajanya, menurut satu pendapat ia adalah seorang Nestorian dan menurut yang lain adalah seorang Yakobit.

Melalui jalur perdagangan bangsa Arab berhubungan dengan bangsa-bangsa Syiria, Persi, Habsyi, Mesir (Qibthi) dan Romawi yang semuanya telah mendapat pengaruh dari kebudayaan Hellenisme. Aliran Kristen yang masuk ke Jazirah Arab adalah aliran Nestorian di Hirah dan aliran Jakob Barady (monofisit) di Ghassan. Daerah Kristen yang terpenting adalah Najran, sebuah daerah yang subur. Penganut agama Kristen tersebut berhubungan dengan Habasyah (Ethiopia), Negara yang melindungi agama ini. Penganut aliran Nestorianlah yang bertindak sebagai penghubung antara kebudayaan Yunani dan kebudayaan Arab pada masa awal kebangkitan Islam. ${ }^{21}$

\section{Trinitas dan Sifat Tuhan}

Dalam tradisi Kristen Klasik, sebenarnya sudah ada formulasi trinitas yang tidak sulit dipahami oleh akal sehat khususnya oleh beberapa teolog muslim. Yaitu ketika oknum-

\footnotetext{
${ }^{20}$ Subhi, Fi Ilm al-Kalam, hlm. 42

${ }^{21}$ Badri Yatim, Sejarah Peradaban Islam: Dirosat Islamiyyah II (Jakarta: PT. Raja Grafindo Persada, 2000), hlm.15
} 
oknum tersebut dikaitkan dengan sifat Tuhan. Seperti dalam formulasi trinitas Neoplatonisme yang kemudian dikenal oleh teolog muslim sebagaimana asal penjelasan trinitas yang dikutip dari Victorianus dan Erigene. Istilah Arab Jud. Zat dan Wujud digunakan sebagai gambaran dari oknum pertama trinitas Neoplatonisme Yunani. Istilah Arab hayat, bikmat, nutk dan ilm digunakan sebagai ekspresi dari oknum kedua dan ketiga. Sedangkan istilah qudroh digunakan sebagai gambaran dari oknum ketiga trinitas Yunani. ${ }^{22}$

Adapun yang termasuk tokoh Kristen Neoplatonis adalah Jamblichus, Theodore of Asine dan Proclus. Jamblichus sebagaimana yang dikutip oleh Damaskus, menggambarkan trinitasnya sebagai Bapa atau substansi (Zat), kekuasaan (qudrab), dan intelek (aqal). Dan Theodore Asine sebagaimana dikutip oleh Proclus menggambarkan trinitasnya sebagai eksistensi (wujud), intelegensi (aqal) dan hidup (hayat). Sedangkan Proclus sendiri mengungkapkan trinitasnya sebagai esensi, substansi atau eksistensi, hidup atau kuasa dan intelek atau intelegensi. Di sisi lain juga ia menggambarkan trinitasnya sebagai goodness (jud), power atau pengetahuan ( $\mathrm{ilm}$ ). Model yang disebut terakhir ini berkaitan dengan trinitasnya Yahya Ibn 'Adisebagai generosity (goodness), Wisdom (ilm), dan Power. ${ }^{23}$ Dan munculnya keyakinan bahwa ketiganya adalah Tuhan berawal dari konsepsi eternalitas, keazalian dan keqadiman sifat-sifat Tuhan tersebut.

Konsepsi mengenai keqadiman sifat-sifat Tuhan tersebut yang kemudian dalam teologi Kristen diformulasikan menjadi doktrin trinitas memiliki pengaruh terhadap konsepsi sifat Tuhan dalam sekte ortodoks Islam seperti 'Asyariah, Sifatiyah dan sebagainya. Maka sekte-sekte Islam inipun meyakini keqadiman sifat-sifat Tuhan. Namun demikian, mereka tidak sampai menganggap sifat-sifat tersebut sebagai Tuhan.

\footnotetext{
${ }^{22}$ Wolfson, The Philosophy, hlm. 124

${ }^{23}$ Wolfson, The Philosophy of Kalam, hlm.124
} 


\section{Pertemuan Teologi Kristen dan Teologi Islam}

Kristen merupakan agama yang besar pengaruhnya terhadap teologi Islam terutama Mu`tazilah. Dalam masalah ketuhanan, kelompok ini terpengaruh oleh Bapak-Bapak gereja Timur yang pada masa Daulah Umayah diberi kedudukan tinggi dalam pemerintahan seperti Sargius Ibn Mansur al-Rumi. Muawiyah pendiri daulah ini menjadikanya seorang sekretaris dan penasehat pribadinya. Dan Yazid sebagai penerusnya tetap memuliakan dan selalu meminta petuah-petuahnya. Sepeninggalnya, Sargius mewariskan kedudukan tersebut kepada anaknya John Damaskus (Yahya al-Dimaski). Ia mengabdi pada pemerintahan Umawi selama beberapa tahun. Setelah berhenti dari pengabdianya, ia menghabiskan usianya dengan menyibukan diri dengan diskusi-diskusi dan kajian-kajian serta menyusun kitab ketuhanan. Demikian pula al-Akhtal, seorang penyair Kristen yang diagungkan oleh Yazid. Ia diberi kedudukan tinggi sebagai penyair istana.

Asimilasi umat Islam dengan umat Kristen pada saat itu memberikan pengaruh yang besar terhadap kedua tradisi ini. Apalagi dari sosok legendaris John Damaskus yang merupakan teolog besar terakhir di gereja Timur dan teolog terbesar di kekristenan Timur. Karya-karyanya dijadikan panduan pada gerejagereja tersebut sebagaimana yang dikatakan J.C. Ayer. Bahkan menurut M.C. Giffert, teologi Kristen mencapai puncaknya pada masa Damaskus. Dari karyanya Al-Iman al-Urtuduksi kita bisa mengetahui posisinya bagaimana ia menyandarkan pembelaan terhadap akidah-akidah agama pada argumentasi rasio. Untuk menguatkan argumentasinya ia menulis sebuah buku tafsir ketuhanan Kristen yang didasarkan pada filsafat logika Aristoteles. Dengan demikian pengaruh Damaskus tidak terbatas pada kekristenan Timur tetapi juga kekristenan Barat dan bukunya tersebut diterjemahkan ke dalam bahasa Latin. Banyak teolog Barat yang memberikan apresiasi dan mempelajarinya seperti Thomas Aquinus, teolog Barat terbesar (673H/1274M). 
jika pengaruhnya sampai tembus ke Barat, kenapa tidak bangsa Arab Muslim yang membesarkanya mendapat pengaruh juga darinya. Pengaruh-pengaruh tersebut sampai ke umat Islam terutama melalui diskusi-diskusi dan perdebatan-perdebatan yang diadakannya. Fenomena ini lazim muncul pada masa Bani Umayah pertama. Mereka sangat toleran terhadap agama sehingga tidak mencegah adanya diskusi-diskusi semacam ini. Toleransi ini mencapai puncaknya pada masa Daulah Abbasiyah khususnya pemerintahan al-Ma mun yang memberikan penghargaan besar terhadap ilmu. Tidak hanya itu, ia sering menghadiri diskusidiskusi yang dilakukan oleh kedua tradisi tersebut seperti diskusi yang diadakan oleh Theodore Abu Qurroh, seorang Uskup Harran dan murid John Damaskus, dengan para teolog Muslim Irak, Syam dan lainya. Theodore memiliki posisi yang tinggi diantara teolog Barat, karena ia mengikuti jejak gurunya dan menggunakan metodenya sehingga menjadi penulis Gereja genius terbesar. ${ }^{24}$

Masa kekuasaan al-Ma`mun inipun dikenang sebagai masa kegemilangan Islam, dimana perkembangan ilmu dan toleransi terhadap agama lain sangat tinggi. Realitas ini bukan sekedar romantisme sejarah bagi umat Islam yang membidaninya tetapi juga diakui oleh semua tradisi, termasuk tradisi Barat dan Kristen sendiri.

\section{Sifat Tuhan dalam Teologi Islam}

a. Monoteisme Mu`tazilah

Semua sekte dalam Teologi Islam mengajarkan monoteisme atau tauhid. Namun dalam hal ini Mu tazilah yang paling tegas dan konsisten dalam menegakan monotesme dibandingkan sekte-sekte Islam lainya. Dalam mempertahankan monoteisme absolut atau tauhid murni, Mu`tazilah mengembangkan teologi

${ }^{24}$ Zuhdi Jarullah, al-Mu tazilah,(Bairut: Muassasah al-Arabiyyah, 1990),hlm.32-33 
via negative $e^{25}$, yaitu menahan diridari memberi sifat atau kualitas apapun kepada Tuhan, dan memilih menyatakan apa-apa yang bukan sifat-sifat Tuhan. Karena pemikiran rasional mereka tidak membenarkan jika Tuhan bersifat dengan sifat yang qadim yang bukan zatNya. Penafian terhadap sifat-sifat ini bukan berarti mereka tidak mengakui Tuhan maha tahu, maha kuasa, maha melihat dan sebagainya. Tetapi supaya mereka tidak mengakui sifat-sifatNya terpisah dan berbeda dari zatNya. Alasanya jika sifat-sifat tersebut tidak dianggap identik dengan zatNya akan menimbulkan qadim yang banyak. Dan hal ini akan mengotori kemahaesaan Allah. Karena itu mereka menafikan sifat-sifat Allah agar tidak ada qadim lain yang menyerupaiNya.

Menurut golongan ini, kalau dikatakan Tuhan memiliki sifat, maka dalam diri Tuhan ada unsur yang banyak, yaitu unsur zat yang disifati dan unsur zat yang melekat pada sifat. Jika dikatakan Tuhan memiliki dua puluh sifat, berarti dia tersusun dari dua puluh satu unsur. Bila empat puluh sifat berarti unsurnya akan berjumlah empat puluh satu. Dan kalau Sembilan puluh Sembilan sifat berarti Tuhan akan terdiri dari seratus unsur. Pemberian sifat kepada Tuhan menurut Mu 'tazilah akan membawa banyaknya jumlah yang qadim.Sedangkan dalam paham teologi yang qadim itu Esa. Kalau iman dalam ajaran biasa adalah tiada Tuhan selain Allah. Maka iman dalam teologi mengambil bentuk tiada yang qadim selain Allah. Oleh karena itu, paham banyak yang qadim membawa paham kepada syirik dan syirik dalam Islam merupakan dosa terbesar yang tidak bisa diampuni Tuhan. ${ }^{26}$

Pemikiran Mu`tazilah ini merupakan antithesis dan ditujukan sebagai counter terhadap pemikiran yang ada baik Sifatiyah,Musyabbihah, Mujassimah dan `Asyariah dari kalangan Islam maupun trinitas Kristen. Bagi Mu`tazilah, pernyataan

${ }^{25}$ Richard C.Martin, Defender of Reason in Islam: Mu`tazilah From Medival School to Modern Symbol, (England Oxford Oneworld, 1997), hlm.68

${ }^{26}$ Harun Nasution, Kaum Mu tazilah Dan Pandangan Rasionalnya, (Jakarta: Yayasan Tridarma Utama, tt), hlm. 18-19 


\section{Sri Dahlia}

'Asyariah bahwa Allah mengetahui dengan ilmu dan hidup dengan sifat hidupNya yang qadim akan memberikan jalan untuk membenarkan trinitas Kristen. ${ }^{27}$ karena ketiga oknumnya : Bapak, Putra dan Roh Kudus oleh mereka dianggap sebagai sifat Tuhan yang qadim dan berdiri sendiri. Latar belakang inilah yang menjadikan Yesus disembah oleh mereka.

Dari sini sangat jelas rasionalisme yang digunakan Mu`tazilah dalam mempertahankan dan membela monoteisme absolut. Maka tidak berlebihan jika para orientalis yang banyak menulis tentang peradaban Islam klasik, golongan ini dijuluki sebagai kaum rasionalis Islam. Dalam sejarah pemikiran Islam, golongan ini meletakan dan menggunakan asas metode rasional (almanhaj al-aqli) dan metode dialektis (almanhaj al-jadali)dalam memformulasikan pokok-pokok akidah dari sumber aslinya al-quran. Metode rasional yang digunakan Mu`tazilah dalam mengesakan Tuhan ini telah membuka jalan bagi munculnya para filosof di kalangan Islam. Tidak mengherankan jika Abu Yusuf Ibn Ishak al-Kindi (w.260H/873M) yang dianggap sebagai filosof pertama adalah penganut faham Mu 'tazilah di bidang akidah. Dan filosof setelahnya Abu Nashar Muhammad Ibn Muhammad alFarabi (w.339H/950M) maupun Abu Ali al-Hussen Ibn Abdullah Ibn al-Hasan Ibn Ali Ibn Sina (w.428H/1037M) juga adalah seorang Mu`tazilah.

Rasionalisme pemikiran Mu`tazilah dalam rangka mengesakan Allah terpengaruh oleh konsepsi ketuhanan Aristoteles mengenai actus purus, sedangkan dalam konsepsi sifat dan zat, pemikiran dan obyeknya, bahwa yang transenden hanya diketahui secara negatif, terpengaruh oleh pemikiran Plotinus.Namun sungguh aneh jika pemikiran yang berasal dari filosof Yunani kuno sebelum Aristoteles dan Plotinus, yakni Empedokles ini secara umum dibanggakan oleh pemikir-pemikir

${ }^{27}$ Abd al-Jabbar, Al-Mughni fi Abwab al-Taubidwa al-'Adl: al-Firaq gha rol Islamiyah J.5. Ed. Muhammad Madzkur, (Mesir al-Dar al-Masyriqiyah, 1960). hlm.86 
Muslim dalam mengesakan Tuhan melalui kesatuan sifat dan zat pada diri Tuhan. ${ }^{28}$ Fenomena seperti ini menurut Fazlur Rahman adalah suatu dalam rangka membela Islam dari serangan-serangan pihak luar. Dalam melakukan untuk pertama kalinya mereka terpaksa membuat sebuah pikiran yang secara sistematis di luar kredo agama Islam. Dan mereka sukses membersihkan umat Islam dari apa yang kemudian disebut "kebudayaan rendah" agama Islam oleh Schleiermacher dalam konteks yang sama pada Kristen abad XIX. ${ }^{29}$ Meskipun kesuksesan ini hanya dinikmati oleh kaum elit akademisi dan itupun dibatasi oleh sekat-sekat teologis dan filosofis. Artinya masyarakat awam yang merupakan mayoritas umat yang tidak berkecimpung dalam permasalahan teologis dan filosofis tidak dapat mencicipi rasionalisme mereka. Sebaliknya, dalam lingkungan tradisional yang merupakan basis 'Asyariah, aliran Mu`tazilah cenderung dimusuhi dan dianggap sebagai sekte yang menyimpang dari ajaran Islam. Buku-bukunya dilarang untuk dipelajari. Maka sumber yang tersedia hanya dari penulis dari teolog Asyariah saja seperti Maqolat al-Islamiyyin karya al-Asyari, al-Farqu Bainal Firaq karya al-Baghdadi dan Al-Milal wa an-Nihal karya al-Syarastani.

b. Sifat-sifat Tuhan perspektif Mu`tazilah

Mu`tazilah merupakan sekte Islam yang tumbuh dan berkembang dalam kebudayaan kosmopolit, saat berkembangnya pengetahuan khususnya helenisme di dunia Islam. Melalui asimilasi yang merupakan hukum alam. Adalah niscaya jika Mu`tazilah terpengaruh oleh pemikiran-pemikiran para filosof Yunani dalam membela dan mempertahankan monoteisme absolut dari serangan golongan-golongan lain seperti trinitas Kristen.

Akidah yang dianut Mu ‘tazilah dalam mengkaji sifat-sifat Tuhan berbeda dengan golongan Islam lainya terutama akidah Hanbaliyah dan Ahli Sunnah. Islam pada awalnya mengharuskan

${ }^{28}$ Majid Fakhri, A History of Islamic Philosophy (London Colombia Unive sity Press, 1970), hlm.73,173

${ }^{29}$ Richard, Defender of hlm.201 


\section{Sri Dahlia}

adanya tauhid, namun hal ini tidak melarang adanya nama-nama yang baik (al-Asma al-Husna) yang dikonsepsikan kepada Tuhan seperti yang diterapkan pada manusia, begitu juga dengan adanya sifat-sifatNya.

Dalam mengatasi ancaman yang bisa menjerumuskan pada politeisme, Wasil bin Atha sebagai pendiri Mu`tazilah menolak eksistensi sifat-sifat Tuhan seperti mengetahui, berkuasa, berkehendak dan hidup. Hal ini tidak berarti bahwa Wasil dan pengikutnya menolak ayat-ayat yang menggambarkan sifat-sifat Tuhan. Sebagai orang Islam yang percaya bahwa al-Qur an adalah wahyu yang disampaikan Tuhan kepada nabi Muhammad, mereka menerima kebenaran ayat-ayat ini bersama dengan kebenaran seluruh ayat lainya. Hanya penafsiran mereka tentang ayat-ayat itu berlainan dengan aliran para teolog lainya. Bagi Mu tazilah al-Rahman, al-Rabim, al-qadir, al-'Alim dan sebagainya bukanlah sifat Tuhan tetapi aspek dari zat atau esensi Tuhan. Bagi mereka Tuhan mengetahui bukan melalui sifat pengetahuan tetapi melaui zatNya. Dengan penafsian seperti ini kaum Mu tazilah memberi gambaran yang Esa kepada diri Tuhan, diri yang tidak tersusun dari lapisan zat dan lapisan sifat tetapi dari satu zat yang memiliki berbagai aspek. Yang dituju kaum Mu tazilah dengan peniadaan sifat-sifat ialah penegasan diri Tuhan. Dengan demikian mereka menjauhi pengertian politeisme. ${ }^{30}$

Sebenarnya Mu'tazilah tidak mengingkari keberadaan sifat-sifat Allah tetapi mereka menolak adanya sifat-sifat yang qadim dan dipahami sebagai tambahan atas zatNya. Dengan berpegang pada pemahaman mengenai keesaan Tuhan, mereka mengakui adanya penyatuan antara zat dan sifat. Artinya menurut mereka zat Allah tidak tesusun dari sesuatu apapun, isi atau lainya. Karena jika zat Tuhan tersusun niscaya masing-masing bagian membutuhkan bagian-bagian lainya. Sementara itu Allah adalah satu dan mempunyai kesempurnaan sehingga Dia tidak

${ }^{30}$ Harun Nasuion, Kaum Mu'tazilah dan Pandangan Rasionalnya, Jakarta: yayasan Tridarma Utama, tt),hlm.19 
membutuhkan yang lain. zatNya tidak terdiri dari betuk dan sisi apapun. Sifat tersebut adalah zat itu sendiri dalam arti zat Allah dan sifatNya satu. Allah maha hidup, mengeahui dan beruasa melalui zatNya. Tidak melalui sifat ilmu, sifat kuasa, sifat hayat dan sifat-sifat lainya yang merupakan tambahan atas zatNya. Berdasarkan argumen ini, kalangan Mu`tazilah menyatakan seperti Abu Hudzail dan Ibrahim Annazzam (w.356H), jika Allah mengetahui dengan sifat ilmu berarti sifat itu merupakan tambahan atas zatNya sebagaimana kita lihat pada diri manusia. Di sana pasti ada sifat dan yang disifati. Ciri-ciri tersebut hanya terjadi pada jisim, padahal Allah bukan jisim. Jika dikatakan sifat-sifat itu berdiri sendiri niscaya akan berakibat pada berbilangnya yang qadim, sedang berbilangnya yang qadim berarti berbilangnya Tuhan. ${ }^{31}$

Tokoh Mu`tazilah lainya Abu Hasyim menolak untuk menggunakan kata sifat dan mengantinya dengan istilah modus. Dia mengatakan sifat-sifat bukanlah sesuatu maupun zat. Ia tidak maujud maupun ma dum dan dapat diketahui kecuali jika dikaitkan dengan zat. Karena dia menganggap hal lebih ringan dari sifat dan lebih sedikit perananya.

Berbeda dengan Abu Hasyim yang memahami sifat sebagai modus, Ma`mar Ibn Ibad (w.144H) pendahulunya, menafsirkan sifat sebagai konsepsi (ma na) sehingga ia dijuluki seorang konseptualis (ashabul ma ani). Menurutnya konsep lebih ringan daripada substansi sifat. Dengan demikian ia mengatakan Allah mengetahui dengan ilmu dan ilmuNya memiliki konsepsi, begitu juga dengan sifat lainya. Dia ingin menjadikan zat Tuhan sebagai suatu yang qadim dan menganggap sifat-sifat terebut hanya sebagai konsepsi kedua yang tidak penting. ${ }^{32}$

Dari sini dapat kita lihat kaum Mu tazilah telah berbeda pendapat mengenai eksistensi sifat-sifat Allah. Ada yang

\footnotetext{
${ }^{31}$ Muhammad 'Atif al-Iraqi, Metode Kritik Falsafah Ibn Rusdh, Terj. Aksin Wijaya (Yogyakarta: IRCiSoD, 2003), hlm.110

${ }^{32}$ Zuhdi, Mu tazilah,,,hlm.76
} 


\section{Sri Dahlia}

mengatakan sifat Allah merupakan zatNya, zat itu sendiri. Ada juga yang berpendapat sifat-sifat Allah merupakan modus-modus dan sebuah konsepsi. Namun demikian, mereka sepakat sifat-sifat itu tidak terpisah dari zatNya. Kesepakatan pendirian Mu tazilah ini adalah dalam rangka memurnikan keesaan Tuhan yang sedang terancam terutama oleh trinitas Kristen dengan oknumoknumnya yang merupakan sifat-sifat yang qadim: wujud, 'ilmu dan hayat dalam bentuk pribadi Bapak, Putra dan Roh Kudus. Ketiga sifat atau pribadi ini diyakini qadimsehingga masing-masing menerima penyembahan yang sama.

Kedua alasan Mutazilah, yakni segala sesuatu yang qadim adalah Tuhan dan tauhid meniadakan dan menolak adanya banyak Tuhan meskipun yang banyak ini menyatu dan tidak bisa dipisahkan dari keazaliaNya, memiliki latar belakang sejarah pada filosof Yahudi Philo melalui bapak-bapak gereja. Alasan pertama $\mathrm{Mu}$ tazilah merupakan perinsip yang dikatakan Philo bahwa Tuhan sendiri qadim. Implikasinya adalah segala sesuatu yang qadim harus menjadi Tuhan. Prinsip ini kemudian diteruskan oleh bapak-bapak gereja seperti Tertullian. Ia mengatakan qadim adalah sifat Tuhan. Ia hanya dimiliki oleh Tuhan sendiri. Pandangan Philonik tersebut juga digunakan oleh bapak-bapak gereja dalam melawan dan menentang adanya yang qadim selain Tuhan. ${ }^{33}$

c. Kristologi Mu`tazilah

Bisyr Ibn Mu `tair (210H), al-Jahid, Abu Ali al-Jubbai dan muridnya Qhadi Abd al-Jabbar merupakan generasi Mu`tazilah penerus yang mengkritik trinitas. Mereka pernah mengadakan kontak langsung dan berdebat dalam forum-forum ilmiah dengan sekte-sekte Kristen ortodoks. Dan hasil interaksi ini dituangkan dalam sebuah buku. Namun sayang sekali karya-karya mereka hilang ditelan masa seiring dengan berlarut-larutnya kebencian umat pada golongan ini. Nampaknya yang masih ada sekarang dan sampai kepada kita adalah al-Mughni karya Abd al-Jabbar yang

${ }^{33}$ Wolfson, The Philosophy...hlm.134 
di dalamnya menjelaskan juga pemikiran kritis gurunya Abu Ali al-Jubbai dan tokoh Mu tazilah lainya terhadap doktrin trinitas. ${ }^{34}$

Kedua tokoh Mu`tazilah ini hidup di alam dimana $\mathrm{Mu}$ `azilah telah mengalami kemajuan pesat di bidang teologi. Mereka menggunakan metode kritik pendahulunya yang sudah bergulat dan mengkaji trinitas dengan bantuan filsafat Yunani dalam membela tauhid. Meskipun sudah ada ayat al-Qur an yang mengkritik trinitas dan mengkafirkanya, namun menurut penulis mereka tidak menggunakan ayat-ayat ini untuk melegitimasi kritiknya. Karena dalam Al-Mughni, abd al-Jabbar tidak pernah menyebut argumentasi literal kitab suci al-Quran. Yang ada hanya argumentasi teologis rasional. Yaitu argumentasi rasional yang dihasilkan dari kajian-kajian konsepsi mereka terhadap sifat-sifat Tuhan. Berbeda dengan Ibn Hazm yang mengunakan argumentasi literalis kitab suci dalam menunjukan kekeliruan doktrin ini. ${ }^{35}$

Dalam Kristologinya, al-Jubbai menyadari adanya satu eksistensi yang qadim dalam keyakinan umat Kristen. Namun menurut mereka kepercayaan ini bertentangan dengan kepercayaan umat Kristen itu sendiri menganai tiga oknum, yang ketiganya adalah qadim. Sebenarnya keberadaan tiga oknum ini basa saja dibenarkan kalau ketiga oknum tersebut tidak menunjuk oknum tertentu. Yakni hanya sifat saja seperti keberadaan Allah yang hidup, mengetahui dan sebagainya. Akan tetapi dalam keyakinan Kristen, oknum-oknum tersebut dipahami sebagai eksistensi yang menunjuk pada zat tertentu. Konsekuensi dari keazalian oknum-oknum tersebut adalah Bapa memiliki sifat yang dimiliki Putra dan Ruh begitu juga sebaliknya. Hal ini menuntut keberadaan Bapa sebagai Putra, Putra sebagai Bapa, Bapa sebagai Ruh dan Ruh sebagai Bapa. ${ }^{36}$

${ }^{34}$ Abd Sattar al-Rain, Al-Aql al-Hurriyah: Dirosah al-Fiker al-Qhadi abd alJabbar, (Bairut al-Mu`ssasah al-Arabiyah, 1980),hlm.196

${ }^{35}$ Ibn Hazm, Al-Fishal...hlm.49

${ }^{36}$ Abd al-Jabbar, Al-Mughni, hlm.85 
Melalui logika tersebut, al-Jubbai menegaskan Putra seharusnya sebagai Putra sendiri. Jika Putra sama dengan Bapa dalam keazalianya, maka ia harus sama juga dengan Bapa dari segi zatNya. Bila Putra sebagai Bapa sepantasnya ia memiliki Putra juga, yaitu ilmu dan kalimat. Dan posisi sebagai Putra meniscayakan adanya Putra yang lain, yakni ilmu dan kalimat dan seterusnya sampai tidak terbatas. Begitu juga terjadi pada Ruh. Hal ini sama kalau Putra memiliki Ruh, ia memiliki Putra sebagaimana Bapa memiiki Putra dan Ruh, karena kesamaan keduanya dari segi keazalian.

Doktrin adanya tiga yang qadim ini bertentangan dengan keyakinan lainnya dalam agama Kristen, yakni yang qadim hanya pencipta saja. Karena ketika mereka meyakini Putra dan Ruh sama qadimnya dengan Bapa sang pencipta. Keyainan yang kedua ini merupakan counter thesis yang pertama mengingat sifatnya yang kontradiktif. Kalau keberadaan apa harus disertai dengan sifat Ruh dan mengetahui harus dengan sifat ilmu. Kenapa tidak kedua oknum ini ditetapkan sebagai kalimat dan ruh saja dan tidak sebagai Tuhan. Jika semuanya dianggap Tuhan, maka niscaya akan muncul tuhan-tuhan yang lain yang tidak terbatas. Sebagaimana tidak terbatasnya sifat-sifat yang diatributkan kepada Tuhan seperti berkuasa, berkehendak dan sebagainya. ${ }^{37}$

Menurut umat Kristen, penetapan terhadap tiga oknum ini tidak berarti menetapkan tiga Tuhan (triteis). Karena ketiganya merupakan satu substansi. Dan penetapan ketiga oknum ini dari segi keberadaanya, bukan dari segi substansi.

Untuk meyakinkan umat Islam mengenai kebenaran trinitas dan dalam rangka mendamaikan antara trinitas dan monoteisme. Timotius seorang Nestorian yang pernah berdebat dengan khalifah al-Mahdi mengenai doktrin ini menggambarkan satu substansi dengan tiga oknum sebagai seorang raja dengan titah dan spiritnya yang tidak dapat dipisahkan darinya. Dia

${ }^{37}$ Abd al-Jabbar Syarh al-Usul,,hlm.249 
merupakan satu raja yang memiliki satu titah dan spirit. Dan tidak dikatakan sebagai tiga raja. Seperti juga matahari yang yang tidak dapat dipisahkan dengan sinar dan panasnya. Fenomena ini tidak dapat dikatakan sebagai tiga matahari. Meskipun pribadi-pribadi trinitas ini nyata dan bukan sekedar nama, Tuhan masih satu. Argumentasi tersebut mencerminkan monoteisme (tauhid) bersifat relatif. Yakni monoteisme yang di dalamnya diperbolehkan adanya bagian-bagian yang qadim, berbeda dan tidak bisa dipisahkan. Analogi seperti ini sudah pernah digunakan oleh bapak-bapak gereja dalam menjelaskan dan membuktikan monoteisme trinitas. ${ }^{38}$

\section{Studi Analisis}

Sebelum para teolog Muslim mengkaji dan mengkritik doktrin trinitas, al-Qur`an sudah terlebih dahulu membicarakan dan mengkritiknya. Ayat 73 dari QS. Al-Maidah membicarakan dan mengkritik keyakinan kepada tiga Tuhan (triteisme) yang diungkapkan dengan istilah tsalisu salasah, yaitu ketiga dari tiga. Secara literal frase ini dapat dipahami bahwa al-Qur an mengkafirkan pihak-pihak yang meyakini kepada keberadaan tiga Tuhan, bukan pada keberadaan tiga oknum. Mengingat misi utama Islam bahkan misi semua nabi sebelumnya termasuk Yesus sendiri adalah tauhid (monoteisme) yang mengharamkan adanya tuhan-tuhan lain yang disembah selain Tuhan yang Esa. namun Permasalahanya adalah, seringkali ayat-ayat ini ditafsirkan oleh para sarjana Muslim klasik maupun modern sebagai kritik dan pengkafiran terhadap trinitas, yang di dalam Kristen sendiri ditolak dan dianggap sebagai bid ’ah. Memang menurut Watt, selama abad-abad itu mungkin sudah ada orang Kristen berpikiran sederhana dan berpendidikan rendah yang kepercayaan efektifnya sebenarnya berupa triteisme. Dan mungkin juga sudah ada beberapa orang seperti itu di Arab pada masa Muhammad. Sepanjang hal ini terjadi demikian dan al-Qur`an menerang

${ }^{38}$ Wolfson, The Philosophy,,,hlm.320 


\section{Sri Dahlia}

triteisme, maka berarti menyerang bid ah Kristen dan orang Kristen ortodoks seiring dengan kritik-kritiknya. ${ }^{39}$ Umat Kristen tidak terima jika keyakinan mereka disamakan dengan triteis sebagaimana diungkapkan Yahya Ibn `Adi. Mereka menganggap trinitas merupakan salah satu bentuk monoteisme.

Adalah tidak adil jika kita menyamakan kepercayaan triteisme dengan trinitas, mengingat yang pertama mengingkari keberadaan yang Esa sedangkan yang kedua mengakui keberadaanya meskipun harus menyertakan oknum-oknumnya yang tiga: Bapa, Putra dan Roh Kudus atau sifat-sifatNya yang tiga: wujud, ilmu dan hayat. Kategori yang terakhir ini sebagaimana yang pertama kali diperkenalkan Yahya Ibn 'Adi dapat memberikan pemahaman yang jelas terhadap trinitas khususnya kepada umat Islam. Karena sifat-sifat Tuhan tersebut tidak asing di telinga seorang muslim yang hidup di lingkungan tradisional yang semenjak kecil dituntut menghafalkan sifat-sifat Tuhan yang dua puluh. Namun sangat disayangkan ketika komparasi oknumoknum dengan sifat-sifat yang pernah dilakukan oleh Bapak gereja Timur ini tidak dilanjutkan oleh generasi penerusnya dari para teolog Kristen. Sehingga mayoritas umat Islam setelahnya tidak dapat memahami formulasi trinitas. Padahal pemahaman yang benarlah yang tidak menjadikan umat ini merasa benar sendiri.

Penulis menganggap Mu`tazilah tidak mengkritisi keberadaan oknum-oknum trinitas, tetapi mereka menolak eksistensinya yang qadim yang berada di luar zat. Artinya jika oknum-oknum tersebut dipahami sebagai yang hadits bisa saja mereka membenarkan trinitas seperti sifat-sifat Tuhan. Keyakinan kepada oknum yang qadim ini menyebabkan penyembahan terhadap Yesus, sang firman Tuhan. Kalau saja firman Tuhan dipahami sebagai yang muhdats maka tidak akan pernah ada penyembahan terhadap diri Yesus.

${ }^{39}$ WM. Watt, Islam dan Kristen Dewasa ini,,,hlm.74 
Sekte-sekte Kristen yang mempercayai kemahlukan Yesus sebenarnya sudah ada beberapa abad sebelum munculnya Mu tazilah. Mereka adalah Sabellian, Arian dan Macedonian yang di kalangan ortodoks ${ }^{40}$ dianggap sebagai golongan heterodoks (bid`ah) sebagaimana Mu`tazilah dianggap heterodoks oleh Islam ortodoks (Asyariah). Karena ketiga sekte Kristen heterodoks ini tidak menganggap Yesus sebagai Tuhan dan tidak pula menyembahnya. Mereka menganggapnya hanya sebagai manusia biasa dan utusan Tuhan. Bahkan Wolfson dalam bukunya The Philosophy of Kalamnya menemukan titik temu persamaan argumentasi kedua gologan heterodoks dari dua tradisi agama yang berbeda tersebut, Islam dan Kristen khususnya mengenai kemakhlukan sifat kalam Tuhan (al-Qur`an:Yesus). Ini merupakan indikasi kuat adanya pengaruh pemikiran golongan Kristen heterodoks pada Islam heterodoks.

Memang benar pada masa pergumulan teologi Kristen terdapat arus kekristenan heterodoks yang diwakili oleh Arianisme, Sabelianisme dan Macedonianisme. Mereka kebanyakan lulusan perguruan tinggi Antiokhia yang beraliran Aristotelian dan bersifat positivis, kurang mistik dan lebih rasional daripada mazhab Aleksandria yang beraliran Platonis yang bersifat gnostis. Maka adalah niscaya ketika Mu tazilah mengkritik pemikiran yang berpangkal pada pemikiran Plato dan gnosis Yunani tersebut karena memiliki epistemologi dan paradigma yang berbeda denganya.

\section{Simpulan}

Kajian trinitas dan sifat Tuhan yang telah dipaparkan di atas merupakan kajian perbandingan teologis filosofis antara kedua tradisi Kristen dan Islam. Tidak cukup hanya dengan pendekatan teologis saja yang sering menyebabkan berat sebelah dan tidak

${ }^{40}$ Secara literal ortodoks berarti yang benar dan lurus tetapi secara ist lah menunjukkan kejumudan, stagnan dan status quo, berlawanan dengan heterodoks 


\section{Sri Dahlia}

fair dalam mengkaji kedua tradisi ini, tetapi juga dibutuhkan pendekatan filosofis yang menjadikan kajian ini berimbang dan dapat memberikan kontribusi pada umatnya untuk bersikap.

Maka sebagai umat Islam dengan rasionalitasnya yang tinggi mampu memahami konsep trinitas yang diyakini umat Kristen. Ketika memahami eksistensi oknum-oknumnya, nalar kita mudah mengakses dengan menghubungkannya dengan konsep sifat Tuhan yang sejak lama kita akui dan pahami keberadaannya. 


\section{Daftar Pustaka}

Abd al-Jabbar, Al-Mughni fi Abwab al-Taubidwa al-'Adl: al-Firaq ghairol Islamiyah J.5. Ed. Muhammad Madzkur, (Mesir alDar al-Masyriqiyah, 1960).

Abd Sattar al-Rain, Al-Aql al-Hurriyah: Dirosah al-Fiker al-Qhadi abd al-jabbar, (Bairut al-Mu`ssasah al-Arabiyah, 1980

Abu Al-Fatih Muhammad Abu al-Karim Ibn Abu BakaralSyahrastani,, Al-Milal wa an-Nihal, (Bairut: Dar al-Fikr, tt)

Ahmad Mahmud Subhi, Fi Ilmi al-Kalam,: Dirosah Falsafiyyah (DM: Dar al-Kutub al-Jamiyyah,1969

Al-Ghozali, Yesus Dalam Pandangan Al-Ghozali, penyaji Muhammad Abdullah Assarqawi, Terj. Hasan Abrari (TK: Pustaka Dai, 1999)

Anton Wesseles, Arab dan Kristen: Gereja-Gereja Kristen di Timur Tengah,

Badri Yatim, Sejarah Peradaban Islam: Dirosat Islamiyyah II (Jakarta: PT. Raja Grafindo Persada, 2000),

C. Groenen, Sejarah Dogma Kristologi: Perkembangan Pemikiran Yesus Kristus pada umat Kristen (Yogyakarta: Kanisius, 1987)

Eliade, Mircea, The Encyclopedia of Religion,New York: Simon and Schister Mc. Milan, 1993

Harry A.Wolfson, The Philosophy of Kalam (London: Harvard University Press, 1976)

Harun Nasution, Kaum Mu'tazilah Dan Pandangan Rasionalnya, (Jakarta: Yayasan Tridarma Utama, tt

Henry C. Theissen \&Vernon D.Doerksen, Teologi Sistematika (Malang: Yayasan Penerbit Gandum Emas, 1997)

HM. Arifin Mpd, Menguak Misteri Ajaran-Ajaran Agama Besar, Jakarta: PT Golden Terayon Press 1997 Cet. Ke-7 


\section{Sri Dahlia}

Majid Fakhri, A History of Islamic Philosophy (London Colombia University Press, 1970

Muhammad 'Atif al-Iraqi, Metode Kritik Falsafah Ibn Rusdh, Terj. Aksin Wijaya (Yogyakarta: IRCiSoD, 2003)

Richards C.Martin, Defender of Reason in Islam: Mu'tazilah From Medival School to Modern Symbol, (England Oxford Oneworld) 1997

TJ De Boer, The History of Philosophy on Islam, (New York: TP,TH0)

WM Watt, Titik Temu Islam dan Kristen: Persepsi dan Salah Persepsi Terj. Zaimudin (Jakarta: Gaya Media Pratama, 1996),

Zuhdi Jarullah, al-Mu tazilah, (Bairut: Muassasah al-Arabiyyah, 1990) 